\title{
PEMANFAATAN WAKTU LUANG PESERTA DIDIK SEKOLAH MENENGAH ATAS
}

\author{
Idris M Noor \\ email: idrishmnoor@yahoo.com \\ Pusat Penelitian Kebijakan Balitbang Kemdikbud
}

\begin{abstract}
Abstrak: Akhir-akhir ini semakin banyak siswa sekolah menengah atas (SMA) dan sekolah menengah kejuruan (SMK) yang tidak dapat memanfaatkan waktu luangnya dan sering melakukan kegiatan negatif dan cenderung bertindak kriminalitas. Hal ini disebabkan oleh kurangnya kesadaran siswa mengorganisasikan dan mengatur waktu luangnya sebaik-baiknya untuk kegiatan-kegiatan yang positif. Penelitian inidilakukan pada tahun 2011 di delapan provinsi di Indonesia dan di setiap provinsi dipilih 1 Kabupaten dan 1 Kota. Tujuan penelitian adalah untuk mendapatkan informasi mengenai kegiatan peserta didik untuk mengisi waktu luangnya di luar jam pelajaran di sekolah. Pendekatan yang digunakan dalam penelitian ini adalah pendekatan campuran kuantitatif dan kualitatif (mixed method) dengan metode evaluasi dan metode studi kasus. Sampel penelitian sebanyak 178 orang guru, peserta didik sebanyak 4103 orang, dan orangtua sebanyak 3747 orang. Alat yang digunakan dalam pengumpulan data penelitian ini adalah kuesioner, pedoman studi dokumentasi, pedoman focus group discussion (FGD), dan pedoman wawancara. Temuan penelitian antara lain peserta didik memilih kegiatan yang sesuai dengan motivasi dan minat mereka. Kegiatan yang cenderung diminati tersebut merupakan kegiatan yang lebih banyak unsur hiburannya. peserta didik masih banyak yang belum mempunyai kemandirian dalam berpikir dan bertindak sesuai dengan potensi dirinya, dan kerjasama orang tua dengan sekolah masih kurang.
\end{abstract}

Kata kunci: waktu luang, siswa, kenakalan remaja, pengaruh, motivasi,

\section{HOW THE SENIOR HIGH SCHOOL STUDENTS SPEND THEIR SPARE TIME}

\begin{abstract}
Nowdays, there has been more and moer students of senior high school (SHS) and vocational school (VS) who cannot manage their time well and often do negative activities that tend to be crime. This is caused by the lack of the students awareness to organize and manage their spare time for positive activities. The objective of the research is to find out the information about the students' activities to use their spare time outside the school hours. This research used mixed method, with evaluation and case study. Sample consisted of 178 teachers, 4103 students, 3747 students' parents in the eight provinces in 2011. Tool of research are questionnair, documentation guide, focus group discussion (FGD) guide, and interview guide. Research finding is that the students tend to choose activities they are interested in or the activities they motivate in, students are not independent both in their thought and action based on their potential, and the collaboration between parents and school is very low.
\end{abstract}

Key words: spare time, students, juvenile delinquent, influence, motivation

\section{PENDAHULUAN}

Akhir-akhir ini semakin banyak siswa sekolah menengah atas (SMA) dan sekolah menengah kejuruan (SMK) yang tidak dapat memanfaatkan waktu luangnya dan sering melakukan kegiatan-kegiatan negatif dan cenderung bertindak kriminalitas. Hal ini disebabkan oleh kurangnya kesadaran siswa mengorganisasikan dan mengatur waktu luangnya sebaik-baiknya untuk kegiatan-kegiatan yang positif.
Hal-hal negatif yang sering dilakukan oleh remaja kita, antara lain seperti yang terungkap dalam data Badan Narkotika Nasional (BNN: 2004) bahwa lebih dari 2 juta remaja Indonesia ketagihan narkoba.

Penyebab kenakalan remaja seperti tersebut diakibatkan oleh antara lain kondisi psikologis remaja, lingkungan rumah dan sekolah yang kurang mendukung, kurang perhatian guru dan orang tua, broken home, tidak ada waktu orang tua untuk membimbing anaknya, ketidaktauan anak itu 
sendiri, kurang ketatnya aturan sekolah dan rumah, pendidikan agama kurang, tidak punya cita-cita masa depan, dan pengaruh teman. Selain itu, persoalan kenalakalan remaja sebenarnya erat kaitanya dengan pendidikan moral dan agama, khususnya mengenai pendidikan karakter bangsa. Pendidikan karakter bangsa menjadi isu penting dalam pelaksanaan pendidikan di sekolah. Salah satu cara dalam mengimplementasikan pendidikan karakter bangsa adalah melalui pemanfaatan waktu luang bagi peserta didik.

Waktu luang tanpa diisi dengan kegiatan yang positif akan menimbulkan berbagai persoalan lingkungan dapat terganggu. Pengisian waktu luang dengan baik dan cara yang sesuai dengan umur remaja, masih merupakan masalah bagi kebanyakan remaja, misalnya; timbulnya rasa bosan dan segan untuk melakukan apa saja merupakan fenomena yang sering kita jumpai (Monks, Knoers, dan Haditono 2002:285). Terkait dengan pemanfaatan waktu, hasil penelitian Muhajir (2007:i, 31, 32, dan 63) menemukan bahwa pemanfaatan waktu dipengaruhi oleh faktor instrisik dan ekstrinsik. Faktor intrinsik antara lain dipengaruhi oleh minat perhatian dan kemauan, motivasi, dan cita-cita. Faktor ekstrinsik dipengaruhi oleh faktor keluarga atau orang tua.

Ditemukan pula bahwa faktor ekstrinsik seperti dorongan orang tua, program sekolah mengenai kegiatan ekstrakurikuler olahraga, adanya pertandingan antar sekolah, keinginan memperoleh prestasi yang baik dalam bidang olahraga, adanya sarana dan prasarana olahraga yang baik, adanya media teknologi yang canggih yang memudahkan peserta didik mengakses informasi termasuk informasi olah raga akan mempengaruhi peserta didik untuk melakukan perbuatan positif. Pengaruh ekstrinsik seperti penghargaan termasuk hadiah, dorongan penonton dalam kegiatan olah raga dan kesenian termasuk dalam kategori berpengaruh sangat tinggi (77\%) dan sikap kepercayaan diri peserta didik SMA dalam mengikuti ekstrakurikuler olahraga sebesar 86,79\% (Effendi,1985:123 dalam Muhajir 2007). Selanjutnya, ditemukan bahwa sebagian sebesar $(86,79 \%)$ peserta didik tertarik mengikuti ekstrakurikuler olahraga karena sesuai dengan kebutuhan atau merasakan bahwa sesuatu akan bermakna bagi dirinya seperti ingin mendapatkan tambahan nilai raport (Effendi,1985:123 dalam Muhajir 2007).

Masih kurangnya kesadaran peserta didik untuk memanfaatkan waktu luang untuk kegiatan yang positif dan lemahnya kontrol serta kurangnya perhatian sekolah dan keluarga terhadap aktivitas anaknya sehingga makin banyak peserta didik yang tidak dapat memanfaatkan waktu luangnya untuk kegiatan yang positif baik di sekolah maupun di luar sekolah merupakan suatu masalah yang harus segera dipecahkan. Akibatnya, peserta didik sering melakukan tindakan-tindakan yang negatif dan cenderung meningkat setiap tahunnya. Oleh karena perlu diketahui kegiatan-kegiatan dan wadah yang dibutuhkan oleh peserta didik yang perlu disediakan oleh sekolah, keluarga, dan lingkungan sekitar.

Berdasarkan permasalahan atau isu-isu yang dikemukakan tersebut di atas, maka perlu dilakukan penelitian dan kajian yang mendalam mengenai efektifitas perubahan LPTK/IKIP menjadi universitas. Tujuan penelitian adalah untuk mendapatkan informasi mengenai (1) kegiatan yang dapat dilakukan oleh peserta didik untuk mengisi waktu luangnya di luar jam pelajaran di sekolah, (2) wadah yang disediakan oleh sekolah bagi peserta didik dalam memanfaatkan waktu luangnya di luar jam belajar, (3) cara guru meningkatkan motivasi peserta didik, (4) wadah yang dibutuhkan peserta didik untuk mengisi waktu luangnya di luar sekolah, (5) wadah yang tersedia di lingungan sekitar yang bisa dimanfaatkan oleh peserta didik untuk mengisi waktu luangnya, dan 6) kepedulian orangtua terhadap pemanfaatan waktu luang peserta didik di luar sekolah.

Kajian teori pendudkung dalam penelitian ini akan dijelaskan sebagai berikut.

a. Hakekat dan Konsep Waktu Luang

Waktu luang (free time) adalah waktu yang dimiliki oleh peserta didik yang tidak atau belum terpakai di luar kegiatan-kegiatan yang telah ditentukan atau yang telah ada. Konsep waktu luang bervariasi tergantung pada pandangan dan pendapat orang yang menilai dan memanfatkannya. Banyak pendapat mengenai definisi dan konsep waktu luang, namun pada intinya adalah waktu luang yang dimiliki oleh peserta didik selain waktu yang dimanfaatkan oleh mereka sebagai pelajar.

Pengertian waktu luang seringkali diasosiasikan dengan tidak melakukan apa-apa dan juga bermalasmalasan, padahal tidak seperti itu. Arti istilah waktu luang terbagi atas 3 dimensi. Dilihat dari dimensi waktu, waktu luang dilihat sebagai waktu yang tidak digunakan untuk "bekerja"; mencari nafkah, melaksanakan kewajiban, dan mempertahankan hidup. Dari segi cara pengisian, waktu luang adalah waktu yang dapat diisi dengan kegiatan pilihan sendiri atau waktu yang digunakan dan dimanfaatkan sesuka hati. Dari sisi fungsi, waktu luang adalah waktu 
yang dimanfaatkan sebagai sarana mengembangkan potensi, meningkatkan mutu pribadi, kegiatan terapeutik bagi yang mengalami gangguan emosi, sebagai selingan dan hiburan, sarana rekreasi, sebagai kompensasi pekerjaan yang kurang menyenangkan, atau sebagai kegiatan menghindari sesuatu (Sukadji dalam Popsy, 2007).

Pemanfaatan waktu luang tergantung dari dorongan individunya dan juga dorongan dari orang lain. Waktu luang dalam konteks pendidikan dimaksudkan bahwa peserta didik menyadari pentingnya waktu luang untuk dimanfaatkan secara sungguh-sungguh melalui kegiatan yang berguna bagi dirinya maupun bagi lingkungan sekitarnya.

Waktu luang yang dimiliki peserta didik dapat diklasifiksikan dalam dua kelompok, yaitu: waktu luang di seklah meliputi waktu pada jam istirahat (dua kali istirahat) dan sebelum dan sesudah jam pelajaran dimulai, sedangkan waktu luang di luar sekolah seperti pada waktu pulang sekolah sampai dengan jam tidur, weekend dan hari libur nasional, dan libur sekolah.

b. Remaja

Masa remaja merupakan sebuah periode dalam kehidupan manusia yang batasan usia maupun peranannya seringkali tidak terlalu jelas. Pubertas yang dahulu dianggap sebagai tanda awal keremajaan ternyata tidak lagi valid sebagai patokan atau batasan untuk pengkategorian remaja. Sebab usia pubertas yang dahulu terjadi pada akhir usia belasan (15-18) kini terjadi pada awal belasan bahkan sebelum usia 11 tahun. Seorang anak berusia 10 tahun mungkin saja sudah (atau sedang) mengalami pubertas namun tidak berarti ia sudah bisa dikatakan sebagai remaja dan sudah siap menghadapi dunia orang dewasa. Ia belum siap menghadapi dunia nyata orang dewasa, meski di saat yang sama ia juga bukan anak-anak lagi.

Berbeda dengan balita yang perkembangannya dengan jelas dapat diukur, remaja hampir tidak memiliki pola perkembangan yang pasti. Dalam perkembangannya seringkali mereka menjadi bingung karena kadang-kadang diperlakukan sebagai anakanak tetapi di lain waktu mereka dituntut untuk bersikap mandiri dan dewasa.

Memang banyak perubahan pada diri seseorang sebagai tanda keremajaan, namun seringkali perubahan itu hanya merupakan suatu tanda-tanda fisik dan bukan sebagai pengesahan akan keremajaan seseorang. Namun satu hal yang pasti, konflik yang dihadapi oleh remaja semakin kompleks seiring dengan perubahan pada berbagai dimensi kehidupan dalam diri mereka. Untuk dapat memhami remaja, maka perlu dilihat berdasarkan perubahan pada dimensi-dimensi tersebut.

Seseorang yang berada pada usia 12-18 tahun dapat dikatakan sebagai remaja (Hurlock, 1981). Pendapat lain memberi batasan usia remaja adalah 1221 tahun (Monks, dkk; 2002) dan berada pada rentang 12-23 tahun (Stanley Hall dalam Santrock (2003). Berdasarkan batasan-batasan yang diberikan para ahli, bisa dilihat bahwa mulainya masa remaja relatif sama, tetapi berakhirnya masa remaja sangat bervariasi, bahkan ada yang dikenal dengan istilah remaja yang diperpanjang dan remaja yang diperpendek.

Remaja adalah masa yang penuh dengan permasalahan. Pernyataan ini sudah dikemukakan jauh pada masa lalu yaitu di awal abad ke-20 oleh Bapak Psikologi Remaja yaitu Stanley Hall. Pada saat itu Stanley Hall mengatakan bahwa masa remaja merupakan masa badai dan tekanan (storm and stress). Masa remaja adalah masa terjadinya krisis identitas atau pencarian identitas diri. Karakteristik remaja yang sedang berproses untuk mencari identitas diri juga sering menimbulkan masalah pada diri remaja (Erickson dalam Monks, dkk, 2000; Santrock, 2003).

Beberapa karakteristik remaja yang dapat menimbulkan berbagai permasalahan pada diri remaja, yaitu: (1) kecanggungan dalam pergaulan dan kekakuan dalam gerakan, (2) ketidakstabilan emosi, (3) adanya perasaan kosong akibat perombakan pandangan dan petunjuk hidup, (4) adanya sikap menentang dan menantang orang tua, (5) pertentangan di dalam dirinya sering menjadi pangkal penyebab pertentangan-pertentang dengan orang tua, (6) kegelisahan karena banyak hal diinginkan tetapi remaja tidak sanggup memenuhi semuanya, (7) senang bereksperimentasi, (8) senang bereksplorasi, (9) mempunyai banyak fantasi, khayalan, dan bualan, dan (10) kecenderungan membentuk kelompok dan kecenderungan kegiatan berkelompok (Gunarsa, 1989) .

Para remaja mulai membuat penilaian tersendiri dalam menghadapi masalah-masalah populer yang berkenaan dengan lingkungan mereka, misalnya: politik, kemanusiaan, perang, keadaan sosial, dan sebagainya (Turiel dalam Gunarsa, 1989). Remaja tidak lagi menerima hasil pemikiran yang kaku, sederhana, dan absolut yang diberikan pada mereka selama ini tanpa bantahan. Remaja mulai mempertanyakan keabsahan pemikiran yang ada dan mempertimbangan lebih banyak alternatif lainnya. Secara kritis, remaja akan lebih banyak melakukan pengamatan ke luar dan membandingkannya dengan hal-hal yang selama ini diajarkan dan ditanamkan kepadanya. Sebagian besar 
remaja mulai melihat adanya kenyataan lain di luar dari yang selama ini diketahui dan dipercayainya. Ia melihat bahwa ada beberapa aspek dalam hidup dan beragam jenis pemikiran yang lain. Baginya dunia menjadi lebih luas dan seringkali membingungkan terutama jika ia terbiasa dididik dalam suatu lingkungan tertentu selama masa kanak-kanak.

Kemampuan berpikir dalam dimensi moral (moral reasoning) pada remaja berkembang karena mereka mulai melihat adanya kejanggalan dan ketidakseimbangan antara yang mereka percayai dengan kenyataan yang ada di sekitarnya. Mereka mempertanyakan dan merekonstruksi pola pikir dengan "kenyataan" yang baru. Perubahan inilah yang seringkali mendasari sikap "pemberontakan" remaja terhadap peraturan atau otoritas yang selama ini diterima bulat-bulat. Hal ini tentu saja akan menimbulkan konflik nilai bagi sang remaja. Konflik nilai dalam diri remaja ini lambat laun akan menjadi sebuah masalah besar, jika remaja tidak menemukan jalan keluarnya. Kemungkinan remaja untuk tidak lagi mempercayai nilai-nilai yang ditanamkan oleh orangtua atau pendidik sejak masa kanak-kanak akan sangat besar jika orangtua atau pendidik tidak mampu memberikan penjelasan yang logis, apalagi jika lingkungan sekitarnya tidak mendukung penerapan nilai-nilai tersebut.

c. Dimensi Psikologis Remaja

Masa remaja merupakan masa yang penuh gejolak. Pada masa ini mood (suasana hati) bisa berubah dengan sangat cepat. Pada masa remaja para remaja mengalami perubahan yang dramatis dalam kesadaran diri mereka (self-awareness). Mereka sangat rentan terhadap pendapat orang lain karena mereka menganggap bahwa orang lain sangat mengagumi atau selalu mengkritik mereka seperti mereka mengagumi atau mengkritik diri mereka sendiri. Anggapan itu membuat remaja sangat memperhatikan diri mereka dan citra yang direfleksikan (self-image). Remaja cenderung untuk menganggap diri mereka sangat unik dan bahkan percaya keunikan mereka akan berakhir dengan kesuksesan dan ketenaran. Pada usia 16 tahun ke atas, keeksentrikan remaja akan berkurang dengan sendirinya jika ia sering dihadapkan dengan dunia nyata. Pada saat itu, Remaja akan mulai sadar bahwa orang lain tenyata memiliki dunia tersendiri dan tidak selalu sama dengan yang dihadapi atau pun dipikirkannya. Anggapan remaja bahwa mereka selalu diperhatikan oleh orang lain kemudian menjadi tidak berdasar. Pada saat inilah, remaja mulai dihadapkan dengan realita dan tantangan untuk menyesuaikan impian dan angan-angan mereka dengan kenyataan.
Para remaja juga sering menganggap diri mereka serba mampu, sehingga seringkali mereka terlihat "tidak memikirkan akibat" dari perbuatan mereka. Tindakan impulsif sering dilakukan; sebagian karena mereka tidak sadar dan belum biasa memperhitungkan akibat jangka pendek atau jangka panjang. Remaja yang diberi kesempatan untuk mempertangungjawabkan perbuatan mereka, akan tumbuh menjadi orang dewasa yang lebih berhati-hati, lebih percaya diri, dan mampu bertanggung jawab. Rasa percaya diri dan rasa tanggung jawab inilah yang sangat dibutuhkan sebagai dasar pembentukan jati-diri positif pada remaja. Kelak, ia akan tumbuh dengan penilaian positif pada diri sendiri dan rasa hormat pada orang lain dan lingkungan. Bimbingan orang yang lebih tua sangat dibutuhkan oleh remaja sebagai acuan bagaimana menghadapi masalah itu sebagai "seseorang yang baru"; berbagai nasihat dan berbagai cara akan dicari untuk dicobanya. Remaja akan membayangkan apa yang akan dilakukan oleh para "idola" nya untuk menyelesaikan masalah seperti itu. Pemilihan idola ini juga akan menjadi sangat penting bagi remaja.

Salah satu topik yang paling sering dipertanyakan oleh individu pada masa remaja adalah masalah "Siapakah Saya?" Pertanyaan itu sah dan normal adanya karena pada masa ini kesadaran diri (self-awareness) mereka sudah mulai berkembang dan mengalami banyak sekali perubahan. Remaja mulai merasakan bahwa "ia bisa berbeda" dengan orangtuanya dan memang ada remaja yang ingin mencoba berbeda. Inipun hal yang normal karena remaja dihadapkan pada banyak pilihan. Karenanya, tidaklah mengherankan bila remaja selalu berubah dan ingin selalu mencoba, baik dalam peran sosial maupun dalam perbuatan. Contoh: anak seorang insinyur bisa saja ingin menjadi seorang dokter karena tidak mau melanjutkan atau mengikuti jejak ayahnya. Ia akan mencari idola seorang dokter yang sukses dan berusaha menyerupainya dalam tingkahlaku. Bila ia merasakan peran itu tidak sesuai, remaja akan dengan cepat mengganti peran lain yang dirasakannya "akan lebih sesuai". Begitu seterusnya sampai ia menemukan peran yang ia rasakan "sangat pas" dengan dirinya. Proses "mencoba peran" ini merupakan proses pembentukan jati diri yang sehat dan juga sangat normal. Tujuannya sangat sederhana; ia ingin menemukan jati diri atau identitasnya sendiri. Ia tidak mau hanya menurut begitu saja keingingan orangtuanya tanpa pemikiran yang lebih jauh.

Banyak orangtua khawatir jika "percobaan peran" ini menjadi berbahaya. Kekhawatiran itu 
memang memiliki dasar yang kuat. Dalam proses "percobaan peran" biasanya orangtua tidak dilibatkan, kebanyakan karena remaja takut jika orangtua mereka tidak menyetujui, tidak menyenangi, atau malah menjadi sangat kuatir. Sebaliknya, orangtua menjadi kehilangan pegangan karena mereka tiba-tiba tidak lagi memiliki kontrol terhadap anak remaja mereka. Pada saat inilah, kehilangan komunikasi antara remaja dan orangtuanya mulai terlihat. Orangtua dan remaja mulai berkomunikasi dengan bahasa yang berbeda sehingga salah paham sangat mungkin terjadi.

Mengingat terjadinya gejolak akibat kelebihan energi yang disebabkan karena adanya perubahan fisik maupun psikis pada remaja, maka perlu dicarikan aktivitas yang dapat menyalurkan kelebihan energi agar mereka tidak menyalurkannya pada kegiatan yang tidak bermanfaat atau bahkan merugikan diri mereka sendiri. Energi yang perlu disalurkan tersebut terutama pada saat mereka memiliki waktu luang agar tidak dimanfatkannya untuk hal-hal atau kegiatan yang negatif.

\section{d Kenakalan Remaja}

Kenakalan remaja biasa disebut dengan istilah Juvenile Delinquent yang berasal dari bahasa Latin, "juvenilis" yang artinya anak-anak, anak muda, ciri karakteristik pada masa muda, sifat-sifat khas pada periode remaja, sedangkan "delinquent " berasal dari bahasa latin "delinquere" yang berarti terabaikan, mengabaikan, yang kemudian diperluas artinya menjadi jahat, nakal, anti sosial, kriminal, pelanggar aturan, pembuat ribut, pengacau peneror, durjana dan lain sebagainya. Juvenile delinquency atau kenakalan remaja adalah perilaku jahat atau kenakalan anakanak muda, merupakan gejala sakit (patologis) secara sosial pada anak-anak dan remaja yang disebabkan oleh satu bentuk pengabaian sosial, sehingga mereka mengembangkan bentuk perilaku yang menyimpang.

Istilah kenakalan remaja mengacu pada suatu rentang yang luas, dari tingkah laku yang tidak dapat diterima sosial sampai pelanggaran status hingga tindak kriminal (Kartono, 2003). Kenakalan remaja merupakan tindakan pelanggaran hukum yang dilakukan oleh remaja, di mana tindakan tersebut dapat membuat seseorang individu yang melakukannya masuk penjara (Hurlock, 1973). Kenakalan remaja sebagai tingkah laku yang menyimpang dari normanorma hukum pidana (Sarwono, 2002), serta dapat merusak dan menggangu, baik terhadap diri sendiri maupun orang lain (Fuhrmann, 1990; Santrock (2003).

e. Faktor-Faktor Yang Mempengaruhi Kenakalan Remaja

Faktor-Faktor yang mempengaruhi kecende- rungan kenakalan remaja menurut Santrock, (2003) lebih rinci dijelaskan sebagai berikut.

Pertama, minat. Minat adalah kecenderungan yang tetap untuk memperhatikan dan mengenai beberapa kegiatan. Kegiatan yang dimiliki seseorang diperhatikan terus menerus yang disertai dengan rasa sayang. Minat sebagai kecenderungan yang menetap dalam subyek untuk merasa tertarik pada bidang atau hal tertentu dan merasa senang berkecimpung dalam bidang itu (Winkel, 1993:28). Minat merupakan kesadaran seseorang bahwa suatu obek, seseorang, suatu soal atau situasi yang mengandung sangkut paut dengan dirinya (Arikunto, 2005:217), serta kecenderungan hati yang tinggi terhadap sesuatu (Hernowo, 2005:19).

Berdasarkan pendapat di atas, dapat dikatakan bahwa minat besar pengaruhnya terhadap belajar atau kegiatan. Peserta didikan yang menarik minat peserta didik lebih mudah dipeserta didiki dan disimpan karena minat menambah kegiatan belajar. Untuk menambah minat, peserta didik di dalam menerima peserta didikan di sekolah diharapkan dapat mengembangkan minat untuk melakukannya sendiri karena minat belajar yang telah dimiliki peserta didik merupakan salah satu faktor yang dapat mempengaruhi hasil belajarnya. Apabila seseorang mempunyai minat yang tinggi terhadap sesuatu hal, maka akan terus berusaha untuk melakukanya sehingga apa yang diinginkannya dapat tercapai.

Kedua, motivasi. Drive is an aroused state that occurs because of psychological needs, while a need is a deprivation that enegizes the drive to eliminate or reduce the deprivation (Santrock 2003:245-2460). Motivasi dapat diartikan sebagai suatu kondisi yang mendorong individu melakukan kegiatan (Sukmadinata, 2003:61). Motivasi terbentuk oleh tenaga-tenaga yang bersumber dari dalam dan dari luar diri individu. Jadi dapat dikatakan bahwa motivasi adalah segala upaya atau keinginan yang mendorong atau menggerakkan seseorang untuk melakukan sesuatu.

Dalam kegiatan belajar mengajar, motivasi adalah faktor yang penting karena hal tersebut dapat mendorong peserta didik untuk belajar. Peserta didik akan berhasil jika mempunyai motivasi. Dalam hal kegiatan selain belajar, motivasi juga dapat menentukan jenis kegiatan yang akan dilakukan oleh peserta didik sehingga menjadikan peserta didik tersebut senang melakukannya.

Motivasi dapat dibedakan menjadi dua macam, yaitu: a) motivasi instrinsik dan b) motivasi ekstrinsik. Motivasi instrinsik adalah motivasi yang bersumber dari dalam diri seseorang atas kesadaran sendiri untuk 
belajar atau melakukan sesuatu. Motivasi ekstrinsik adalah motivasi yang datang dari luar diri peserta didik yang menyebabkan peserta didik tersebut melakukan sesuatu. Dalam memberikan motivasi, seorang guru harus mampu memberikan dorongan pada peserta didik agar peserta didik mempunyai inisiatif untuk menekuni pendidikan atau kegiatan lain yang bemanfaat baginya atas kemauanya sendiri. Guru di sekolah harus mampu menciptakan kegiatankegiatan yang dapat mendorong dan memotivasi peserta didik untuk memanfatkan waktu luangnya dengan baik. Melalui kegiatan yang inovatif dan menarik, peserta didik akan terdorong untuk melakukannya tanpa ada paksaan.

Ketiga, bakat, yaitu kemampuan tertentu yang telah dimiliki seseorang sebagai kecakapan pembawaan. Bakat dapat diartikan sebagai kemampuan bawaan, sebagai potensi yang masih perlu dikembangkan dan dilatih agar dapat terkejut (Munandar, 1999:17). Selain itu, bakat juga merupakan kemampuan individu untuk melakukan tugas tanpa banyak bergantung pada upaya pendidikan dan latihan (Muhibbinsyah, 2002:136).

Dari pendapat di atas, jelaslah bahwa tumbuhnya keahlian tertentu pada seseorang sangat ditentukan oleh bakat yang dimilikinya yang berpengaruh terhadap tinggi rendahnya prestasi peserta didik pada bidang-bidang tertentu, baik dalam bidang akademik maupun non akademik. Dalam memilih kegiatan, bakat memegang peranan penting dalam mencapai prestasi yang baik. Sehubungan dengan itu, guru atau orang tua sebaiknya tidak memaksa anaknya untuk melakukan sesuatu yang tidak sesuai dengan bakatnya karena akan merusak keinginan anak tersebut.

Keempat, identitas. Masa remaja ada pada tahap di mana krisis identitas versus difusi identitas yang harus di atasi (Erikson dalam Santrock, 2003). Perubahan biologis dan sosial memungkinkan terjadinya dua bentuk integrasi terjadi pada kepribadian remaja: (1) terbentuknya perasaan akan konsistensi dalam kehidupannya dan (2) tercapainya identitas peran, kurang lebih dengan cara menggabungkan motivasi, nilai-nilai, kemampuan dan gaya yang dimiliki remaja dengan peran yang dituntut dari remaja. Delinkuensi pada remaja, terutama ditandai dengan kegagalan remaja untuk mencapai integrasi yang kedua, yang melibatkan aspek-aspek peran identitas. Remaja yang memiliki masa balita, masa kanak-kanak atau masa remaja yang membatasi mereka dari berbagai peranan sosial yang dapat diterima atau yang membuat mereka merasa tidak mampu memenuhi tuntutan yang dibebankan pada mereka, mungkin akan memiliki perkembangan identitas yang negatif. Beberapa dari 19 remaja ini mungkin akan mengambil bagian dalam tindak kenakalan, oleh karena itu kenakalan adalah suatu upaya untuk membentuk suatu identitas, walaupun identitas tersebut negatif (Erikson dalam Santrock, 2003) .

Kelima, kontrol diri. Kontrol diri mempunyai peranan penting dalam kenakalan remaja. Pola asuh orangtua yang efektif di masa kanak-kanak (penerapan strategi yang konsisten, berpusat pada anak dan tidak aversif) berhubungan dengan dicapainya pengaturan diri oleh anak. Selanjutnya, dengan memiliki ketrampilan ini sebagai atribut internal akan berpengaruh pada menurunnya tingkat kenakalan remaja.

Keenam, usia. Munculnya tingkah laku anti sosial di usia dini berhubungan dengan penyerangan serius nantinya di masa remaja, namun demikian tidak semua anak yang bertingkah laku seperti ini nantinya akan menjadi pelaku kenakalan, seperti hasil penelitian dari McCord dalam Kartono, (2003) yang menunjukkan bahwa pada usia dewasa, mayoritas remaja nakal tipe terisolir meninggalkan tingkah laku kriminalnya. Paling sedikit $60 \%$ dari mereka menghentikan perbuatannya pada usia 21 sampai 23 tahun.

Ketujuh, jenid kelamin. Remaja laki- laki lebih banyak melakukan tingkah laku anti sosial daripada perempuan. Menurut catatan kepolisian Kartono (2003) pada umumnya jumlah remaja laki- laki yang melakukan kejahatan dalam kelompok gang diperkirakan 50 kali lipat daripada gang remaja perempuan.

Kedelapan, proses keluarga. Faktor keluarga sangat berpengaruh terhadap timbulnya kenakalan remaja. Kurangnya dukungan keluarga, seperti kurangnya perhatian orangtua terhadap aktivitas anak, kurangnya penerapan disiplin yang efektif, kurangnya kasih sayang orangtua dapat menjadi pemicu timbulnya kenakalan remaja. Pengawasan orangtua yang tidak memadai terhadap keberadaan remaja dan penerapan disiplin yang tidak efektif dan tidak sesuai merupakan faktor keluarga yang penting dalam menentukan munculnya kenakalan remaja. Perselisihan dalam keluarga atau stres yang dialami keluarga juga berhubungan dengan kenakalan. Faktor genetik juga termasuk pemicu timbulnya kenakalan remaja, meskipun persentasenya tidak begitu besar (Gerald Patterson dkk. dalam Santrock, 2003).

Kesembilan, pengaruh teman sebaya. Memiliki teman-teman sebaya yang melakukan kenakalan 
meningkatkan risiko remaja untuk menjadi nakal. Pada sebuah penelitian terhadap 500 pelaku kenakalan dan 500 remaja yang tidak melakukan kenakalan di Boston, ditemukan persentase kenakalan yang lebih tinggi pada remaja yang memiliki hubungan reguler dengan teman sebaya yang melakukan kenakalan (Santrock, 2003).

Kesepuluh, kelas sosial ekonomi. Ada kecenderungan bahwa pelaku kenakalan lebih banyak berasal dari kelas sosial ekonomi yang lebih rendah dengan perbandingan jumlah remaja nakal di antara daerah perkampungan miskin yang rawan dengan daerah yang memiliki banyak privilege diperkirakan 50:1 (Kartono, 2003). Hal ini disebabkan kurangnya kesempatan remaja dari kelas sosial rendah untuk mengembangkan ketrampilan yang diterima oleh masyarakat. Mereka mungkin saja merasa bahwa mereka akan mendapatkan perhatian dan status dengan cara melakukan tindakan anti sosial. Menjadi "tangguh" dan "maskulin" adalah contoh status yang tinggi bagi remaja dari kelas sosial yang lebih rendah, dan status seperti ini sering ditentukan oleh keberhasilan remaja dalam melakukan kenakalan dan berhasil meloloskan diri setelah melakukan kenakalan.

\section{METODE PENELITIAN}

Pendekatan yang digunakan dalam penelitian ini adalah pendekatan campuran kuantitatif dan kualitatif (mixed method) dengan metode evaluasi dan metode studi kasus. Metode evaluasi digunakan untuk memperoleh data kuantitatif, sedangkan metode kasus untuk memahami kondisi individu, kelompok atau situasi tertentu secara lebih rinci (Lodico, Spaulding, Voegtle, 2006:269). Selanjutnya, case studies can establish cause and effect, indeed one of their strengths is that they observe effects in real contexts, recognizing that context is a powerful determinant of both causes and effects (Cohen, Manion, \& Morrison,2007:252). Dengan demikian pemilihan studi kasus dalam penelitian ini untuk memahami kasus-kasus tertentu yang lebih mendalam sehingga dapat dilhat penyebab dan effek dari konteks yang terjadi.

Penelitian ini dilakukan pada tahun 2011 di delapan provinsi yaitu: Jawa Barat, Kalimantan Selatan, DKI Jakarta, Sulawesi Selatan, Jawa Timur, Sumatera Utara, Jawa Tengah, dan DIY Yogyakarta. Setiap provinsi dipilih 1 Kabupaten dan 1 Kota, yaitu: Kabupaten/Kota Bandung, Banjarmasin, Jakarta, Makasar, Malang, Medan, Semarang, dan Yogjakarta.

Populasi penelitian adalah semua siswa sekolah menengah atas (SMA) dan sekolah menengah keju- ruan (SMK) di delapan provinsi. Sampel penelitian sebanyak 178 orang guru, peserta didik sebanyak 4103 orang, dan orangtua sebanyak 3747 orang. Data diambil 8 provinsi, yaitu: Jawa Barat, Kalimantan Selatan DKI Jakarta, Sulawesi Selatan, Jawa Timur Sumatera Utara, Jawa Tengah, dan DIY Yogyakarta. Setiap provinsi dipilih 1 Kabupaten dan 1 Kota, yaitu: Kabupaten/Kota Bandung, Banjarmasin, Jakarta, Makasar, Malang, Medan, Semarang, dan Yogyakarta. Masing-masing Kota atau Kabupaten dipilih 1 SMA dan 1 SMK yang mewakili daerah perkotaan dan pedesaan. Masing-masing sekolah dipilih satu rombongan belajar kelas 11. Respoden orangtua adalah orang tua peserta didik yang dijadikan sebagai sampel.

Alat pengumpul data menggunakan instrument, yaitu isntrumen peserta didik, instrument guru, dan instrument orangtua peserta didik dan pedoman wawancara. Alat yang digunakan dalam pengumpulan data penelitian ini adalah kuesioner, pedoman studi dokumentasi, pedoman focus group discussion (FGD), dan pedoman wawancara. Pengumpulan data penelitian dilakukan dilakukan dengan teknik: mengumpulkan informasi dengan cara meminta responden untuk mengisi kuesioner, menganalisis data sekunder dari dokumen-dokumen terkait, melakukan FGD, dan wawancara terbatas dengan nara responden.

Data penelitian ini dianalisis dengan menggunakan dua cara yaitu analisis data kuantitatif dilakukakn dengan cara mempersentasekan jawaban nara sumber (responden) dan dikualitatifkan dalam bentuk kecil, sedang, atau paling banyak. Data yang sudah dikualitatifkan tersebut dibahas secara sistematis yaitu dengan cara menguraikan, mensintesis, membandingkan, mengkombinasikan, melakukan triangulasi data dengan hasil penelitian orang lain, dan memberikan komentar atau argumentasi. Data dari dokumen (secondary data) dianalisis dengan cara mendata, mengklasifikasi, mengurutkan, menganalisis, dan menyimpulkan. Kedua data tersebut (data primer dan sekunder) dikombinasikan dan disimpulkan.

\section{HASIL DAN PEMBAHASAN}

Kegiatan yang dapat dilakukan oleh peserta didik untuk mengisi waktu luangnya di luar jam pelajaran di sekolah adalah sebagai berikut.

Pertama, program dan kegiatan sekolah yang mereka lakukan adalah membuka internet, menyelesaikan tugas dari guru, diskusi mengenai pelajaran, dan olah raga, namun mereka jarang dan tidak pernah melakukan budidaya pertanian dan rekayasa 
teknologi.

Kedua, peserta didik kurang berminat mengikuti kegiatan olah raga yang tersedia di sekolahnya. Namun, dari beberapa kegiatan yang diprogramkan oleh sekolah yang paling sering diikuti oleh peserta didik adalah kegiatan olah raga, (futsal, bola basket, sepak bola, dan bulu tangkis, dan yang paling tidak diminati oleh mereka adalah olah raga tenis dan atletik), kemudian kegiatan ekstra kurikuler seperti kegiatan olah raga kesenian. Kegiatan kelompok ilmiah remaja kurang dilaksanakan oleh sekolah. Kegiatan paskibrata juga hanya diikuti oleh sebagian kecil peserta didik.

Ketiga, program kesenian yang paling diminati adalah seni suara dan seni musik, dan yang paling tidak disukai adalah seni keramik dan seni pahat, tapi kalau dilihat secara individu kegiatan seni yang disediakan oleh sekolah, seni musik sebenarnya kurang diminati oleh sebagian peserta didik. Urutanya adalah seni suara, seni musik, seni drama, seni tari, seni lukis, seni pahat dan seni keramik.

Keempat, secara umum kegiatan bimbingan belajar dan rekreasi belum banyak diminati oleh para peserta didik untuk mengisi waktu luang selama berada di luar sekolah.

Kelima, motivasi peserta didik memanfaatkan waktu luangnya secara berturut-turut karena ingin berprestasi dalam meningkatkan nilai, membantu orang tua, menjaga ketertiban lingkungan, atas dorongan orang tua dan guru, dan meningkatkan ketahanan fisik.

Keenam, manfaat bagi peserta didik setelah mengikuti kegiatan dalam mengisi waktu luangnya adalah mereka lebih aktif, bertanggung jawab, lebih mandiri, bersosialisasi, kreatif, berani mengemukakan pendapat, dan prestasinya meningkat.

Wadah yang disediakan oleh sekolah bagi peserta didik dalam memanfaatkan waktu luangnya di luar jam belajar. Peserta didik lebih menyukai wadah ekstrakurikuler seperti olahraga dan kerohanian, paskibra dan penambahan pelajaran, studi wisata, dan kegiatan bakti sosial.

Cara guru meningkatkan motivasi peserta didik yaitu: (1) guru memotivasi peserta didik dengan cara menginformasikan tentang pentingnya kegiatan dalam mengisi waktu luang, memberikan ilustrasi tentang pentingnya kegiatan dalam mengisi waktu waktu luang bagi, mewajibkan peserta didik untuk mengikuti kegiatan, diskusi antara guru dan peserta didik, dan memberikan penghargaan. Sebaliknya, guru tidak pernah memberikan hukuman bagi yang tidak mengikuti kegiatan; (2) dalam menyusun rencana kegiatan, guru mengacu pada program tahunan sekolah, kurikulum, rencana umum sekolah dan komite sekolah, acuan program pemerintah, dan saran masukan orang tua peserta didik; (3) penyusunan kegiatan dilakukan dengan cara diskusi dengan berbagai pihak, guru-guru, kepala sekolah, komite sekolah, peserta didik, dan dinas pendidikan kabupaten/kota, dan masukan dari orang tua peserta didik; dan (4) kendala yang mempengaruhi pesrta didik dalam memanfaatkan waktu luangnya adalah pengaruh teman, kurang berminat dalam kegiatan yang tersedia, tidak ada motivasi untuk berprestasi, tidak ada kemauan untuk meningkatkan nilai, dan tidak ada dorongan guru dan orang tua.

Wadah yang dibutuhkan oleh peserta didik untuk mengisi waktu luangnya di luar sekolah. Wadah yang dibutuhkan oleh peserta didik untuk mengisi waktu luangnya di luar sekolah adalah warnet, sarana keagamaan, sarana olah raga, sarana bimbel, sarana kesenian, dan sarana karang taruna, sedangkan wadah yang disukai berturut-turut adalah: sarana olah raga, sarana keagamaan, sarana bimbingan belajar, sarana kesenian, sarana karang taruna, dan sarana warnet.

Wadah yang tersedia di lingkungan sekitar (di luar sekolah) yang bisa dimanfaatkan oleh peserta didik untuk mengisi waktu luangnya. Wadah dan sarana yang tersedia sudah cukup memadai bagi peserta didik untuk memanfaatkan waktu luang dalam melakukan kegiatan yang positif. Namun, baru sedikit peserta didik yang sudah memanfaatkan sarana yang tersedia dalam mengisi waktu luangnya untuk kegiatan yang positif.

Kepedulian orangtua terhadap pemanfaatan waktu luang anak di luar sekolah (di rumah). Hampir semua orang tua peserta didik mengetahui kegiatan yang dilakukan anaknya selama berada di luar rumah. Anak memiliki kemauan untuk memanfaatkan waktu luang dalam melakukan kegiatan yang positif. Pendapat orang tua peserta didik terhadap motivasi anak (peserta didik) dalam pemanfaatan waktu luang lebih positif dibanding dengan pendapat anak (peserta didik).

\section{PENUTUP}

\section{Kesimpulan}

Dari temuan dan pembahasan di atas, dapat disimpulkan, sebagai berikut. Berdasarkan kegiatan yang paling disukai oleh peserta didik dalam memanfaatkan waktu luangnya seperti membuka internet dan olah raga (futsal, bola basket, sepak bola, dan bulu tangkis), maka dapat disimpulkan bahwa peserta didik memilih kegiatan-kegiatan yang sesuai dengan motivasi dan minat mereka. Kegiatan-kegiatan 
yang cenderung diminati tersebut merupakan kegiatan yang lebih banyak unsur hiburannya. Hal ini dapat dilihat bahwa kegiatan yang jarang dan tidak pernah diikuti adalah tambahan pelajaran atau bimbingan belajar serta kegiatan lain seperti budidaya pertanian dan rekayasa teknologi, seni tari, seni lukis, seni pahat, dan seni keramik. Hal ini mengindikasikan bahwa peserta didik kurang berminat terhadap kegiatan-kegiatan yang bersifat skill yang dapat menghasilkan atau meningkatkan kompetensi baik kompetensi akademik maupun kompetensi produksi. Peserta didik lebih berminat pada kegiatan-kegiatan yang bersifat hiburan.

Mengenai pengaruh teman dapat disimpulkan bahwa peserta didik masih banyak yang belum mempunyai kemandirian dalam berpikir dan bertindak sesuai dengan potensi dirinya yang dapat dikembangkan menjadi potensi yang lebih menguntungkan masa depan yang lebih baik.

Program sekolah khususnya program peningkatan kemampuan akademik yang dapat dilakukan melalui ekstra kurikuler masih sangat minim yang dapat memotivasi peserta didik. Ternyata sekolah lebih banyak menciptakan kegiatan-kegiatan yang kurang diminati peserta didik. Namun, peserta didik yang sudah dapat mengendalikan diri dan mengetahui arah dan tujuan untuk masa depan lebih mendominasi kegiatan-kegiatan yang diprogramkan oleh sekolah khususnya mengenai tambahan jam pelajaran, kesenian, dan olah raga.

Kepedulian orang tua sangat penting karena orang tua mempunyai pengaruh yang besar terhadap perubahan tingkah laku anak. Namun, kerjasama orang tua dengan sekolah masih kurang. Hal ini terlihat masih banyak orang tua yang belum memahami kegiatan-kegiatan yang deprogramkan oleh sekolah untuk peserta didik.

\section{Saran}

Dari simpulan temuan di atas, dapat diusulkan beberapa opsi kebijakan, yaitu: sekolah membuat kebijakan tentang penyusunan program seni yang menarik dan menghibur sekaligus mempertahankan budaya bangsa seperti tari Aceh, Bali, dan tari-tarian daerah lain. Demikian juga program olah raga seperti olah raga futsal, atletik, sepak bola, catur, basketball, bulu tangkis, dan lainnya. Disamping itu, sekolah perlu membuat program-program yang inovatif yang diminati oleh peserta didik agar mereka mau mengikutinya, seperti program SMS Madly yang memberikan informasi pada orangtua tentang kegiatan anaknya di sekolah, dan di sekolah di setiap pojok ruangan perlu ada internet/intranet yang tidak ada program negatifnya. Sekolah perlu membuat program fullday learning (belajar penuh bukan belajar paroh hari). Sekolah juga perlu memperbanyak program kerohanian yang inovatif dan tidak membosankan, seperti sebelum masuk pelajaran peserta didik diajarkan untuk berdzikir bersama.

Sekolah juga dapat menentukan kebijakan bagi siswa agar mereka memilih kegiatan-kegiatan yang dapat meningkatkan nilai akademik dan prestasi non akademik seperti tambahan pelajaran, olah raga, dan kesenian dan menghindari kegiatan-kegiatan yang mengarah pada kenakalan remaja. Mengurangi untuk menghabiskan waktu di internet khususnya di warnet karena ada kecenderungan meninbulkan akses pikiran negatif seperti permainan yang membuat remaja stress, film-film porno, dan sebagainya. Namun, disarankan agar peserta didik lebih banyak membuka internet untuk mencari bahan belajar dan mempelajari hal-hal yang dapat membantu meningkatkan kemampuan akademis.

Sekolah membuat kebijakan tentang peran guru dalam menyusun program, yaitu: guru perlu memperhatikan minat dan motivasi peserta didik dalam memilih kegiatan yang diikutinya agar lebih bermanfaat bagi dirinya.

Sekolah membuat kebijakan tentang perlunya orang tua, masyarakat dan sekolah berkoordinasi agar dapat menciptakan sarana yang dapat mendorong peserta didik untuk memanfaatkan waktu luangnya dengan hal-hal yang positif. Bagi orang tua mengawasi dan mengatur kegiatan anaknya di rumah dan lebih mengutamakan pendidikan agama.

Selain itu, Dinas penididikan perlu membuat kebijakan tentang ketentuan-ketentuan dan pedoman sekolah dalam membuat sentra program internet di sekolah. Program yang ada di sekolah juga diketahui oleh Dinas Pendidikan, sehingga ada link/komunikasi. Dinas pendidikan juga perlu memprogramkan interconecting fasilitas belajar internet.

\section{DAFTAR PUSTAKA}

Arikunto, S. (2000). Manajemen penelitian. Jakarta: PT. Asdi Mahasatya.

Badan Narkotika Nasional (2004)

Cohen, L., Manion. L. \& Morrison. K . (2007). Research methods in education. Routledge 270 Madison Avenue New York, NY 10016

Cresweel, J.W. (2010). Research Design. Pendekatan Kualitatif, Kuantitatif, dan Mixed. Third Edition. Osage publications. Thousand Oaks California 91320.2009. Terjemahan.Ahmad Fawaid. 
Penerbit Pustaka Pelajar, Celeban Timur UH III/548 Yogyakarta.

Fuhrmann, B.S. (1990). Adolescence, adolescent. Illinois: scott, foresman/little brown higher education. http:/ / deviah.hostei.com/index.php diakses pada 7 November 2009

Gunarsa, S. D. (1989). Psikologi perkembangan: Anak dan remaja. Jakarta: BPK. Gunung Mulia.

Hernowo. (2005). Menjadi guru yang mampu mengajar secara menyenangkan. Bandung. Mizar Learning Center.

Hurlock, E.B. (1991). Psikolgi perkembangan suatu pendekatan sepanjang rentang kehidupan (Terjemahan oleh Istiwidayanti dan Soedjarwo). Jakarta: Penerbit Erlangga.

Kartono, K. (2003). Patologi sosial 2: Kenakalan remaja. Jakarta: CV. Raja Grafindo Persada.

Lodico. M. G., Spaulding. D.T., Voegtle. K H. (2006). Methods in educational research. From theory to practice. John Wiley \& Sons, Inc. Jossey-Bass A Wiley Imprint 989 Market Street, San Francisco, CA 94103-1741 www.josseybass.com.

Monks, F. J., Knoers, A. M. P., \& Haditono, S. R. (2002). Psikologi perkembangan pengantar dalam berbagai bagiannya. Yogyakarta: Gadjah Mada University Press.

Masngudin. (2004). Kenakalan remaja sebagai perilaku menyimpang dan hubungannya dengan keberfungsian sosial keluarga. Diakses dari http:/ / www.depsos.go.id/Balitbang/Puslitbang UKS/2004/Masngudin.htm diakses pada 5 November 2009.

Moleong, L. J. (2000). Metodologi penelitian kualitatif. Bandung: PT. Remaja Rosdakarya.

Muhajir, A. (2007). Faktor-faktor yang mempengaruhi minat peserta didik kelas $X$ dalam mengikuti kegiatan ekstrakurikuler olahraga di SMA Islam Sultan Agung I Semarang Tahun Ajaran 2006/2007. Skripsi Universitas Negeri Semarang.
Munandar, U. (1999). Mengembangkan bakat dan kreativitas anak sekolah. Jakarta. PT. Gramedia Widia Sarana Indonesia.

Popsy, T. (2007). Jurnal psikologi populer. Diakses dari situs http://popsy.wordpress. com/2007/06/05/mengisi-celah-waktu-luang pada tanggal 1 Pebruari 2012

Rahayu. (2009). Kenakalan Remaja. Diakses dari situs http:/ / eka-punk.blogspot.com/2009/03/1. html pada 11 November 2009.

Rey, J. (2002). More than just the blues: understanding serious teenage problems. Sydney: Simon \& Schuster.

Santrok, J. W. (2003). Adolescence (Perkembangan Remaja). Terjemahan. Jakarta: Penerbit Erlangga.

Sarwono, S. (1989). Psikologi Remaja. Jakarta. Rajawali. Strauss, A., \& Corbin, J. (1990). Basic qualitative research. Grounded theory, procedures and techniques. London: Sage Publications, Inc.

Sugiarto, I. (2004). Mengoptimalkan data kerja otak dengan berpikir holistik dan kreatif. Jakarta: PT Gramedia Pustaka Utama.

Sukmadinata, N. S. (2003). Landasan psikologi proses pendidikan. Bandung. PT. Remaja Rosdakarya.

Syah, M. (2002). Psikologi pendidikan dengan pendekatan baru. Bandung: PT Remaja Rosda Karya, 2002.

Undang-Undang nomor 20 tahun 2003 tentang Sistem Pendidikan Nasional

Winkel, W.S. (1993). Psikologi pendidikan dan evaluasi belajar. Jakarta. PT. Gramedia Widia Sarana Indonesia.

Wisudo. (2005). Kenakalan remaja. Kompas, 19 Februari 2005.

Yusrina. (2006). Pengaruh Pendidikan Agama Islam terhadap Pembentukan Akhlak Peserta didik di SMP YPI Cempaka Putih Bintaro. Diakses dari situs http://idb4.wikispaces.com pada 11 November 2009 